\title{
PENGEMBANGAN BOOKLET UNTUK MEMPERKENALKAN BENTUK COPING SKILLS DALAM MENGHADAPI KEKERASAN DALAM RUMAH TANGGA PADA PESERTA DIDIK SMA NEGERI 81 JAKARTA
}

\author{
Gantina Komalasari ${ }^{1}$ \\ Indri Septiyani Surya ${ }^{2}$ \\ Hilma Fitriyani ${ }^{3}$
}

\begin{abstract}
Abstrak
Peserta didik pada tingkat Sekolah Menengah Atas (SMA) rentan mengalami konflik dengan orang tua. Konflik yang terus menerus terjadi dapat menimbulkan KDRT di antara peserta didik dan orang tua. Peserta didik perlu memiliki suatu keterampilan untuk dapat menyelesaikan masalah. Penelitian ini memiliki tujuan untuk mengembangkan media booklet untuk memperkenalkan bentuk coping skills dalam menghadapi kekerasan dalam rumah tangga KDRT pada peserta didik SMA Negeri 81 Jakarta. Penelitian ini termasuk dalam Research and Development $(R \& D)$ dengan menggunakan model ADDIE (Analyze, Design, Development, Implementation, Evaluation). Penelitian ini dilakukan di SMA Negeri 81 Jakarta dengan menggunakan metode judgemental sampling atau purposive sampling. subjek penelitian kelas XII yang berjumlah 108 peserta didik. Pengumpulan data dengan menggunakan teknik wawancara dan penyebaran angket kepada peserta didik. Hasil uji validasi ahli media persentase sebesar $98 \%$ (Sangat layak), uji validasi ahli konten pertama persentase sebesar 90\% (Sangat layak) dan ahli konten kedua persentase sebesar 93\% (Sangat layak). Hasil uji coba pada kelompok kecil persentase sebesar 93\% (Sangat layak) pada penilaian media dan 83\% (Sangat layak) pada ketercapaian tujuan intruksional. Booklet untuk memperkenalkan bentuk coping skills dalam menghadapi KDRT pada peserta didik SMAN 81 Jakarta dapat dinyatakan "Sangat Layak" Booklet terdiri dari dua bagian, Bagian I menjelaskan ruang lingkup KDRT dan coping skills. Bagian II menjelaskan penerapan coping skills dalam menghadapi KDRT.

Kata Kunci: Model ADDIE, Booklet, Coping skills, KDRT
\end{abstract}

\section{Abstract}

Students at the high school level are vulnerable to conflict with parents. Continuous conflict can cause domestic violence among students and parents. This study has the objective to develop media booklet to introduce forms of coping skills in dealing with domestic violence among students high school state 81 Jakarta. This study was included in Research and Development $(R \& D)$ by using a model ADDIE (Analyze, Design, Development, Implementation, Evaluation). This research was conducted in high school state 81 Jakarta using judgmental sampling or purposive sampling. XII class research subjects totaling 108 students. Collecting data using interview techniques and questionnaires to students. The results of the validation test media experts percentage of $98 \%$ (very feasible), expert validation test first content percentage of $90 \%$ (very feasible) and experts both content percentage of $93 \%$ (very feasible). The results of trials on a small group a percentage of $93 \%$ (very feasible) on the assessment of the media and 83\% (very feasible) on the achievement of

\footnotetext{
${ }^{1}$ Universitas Negeri Jakarta, gantina-komalasari@unj.ac.id

${ }^{2}$ Universitas Negeri Jakarta, indriseptiyanis@gmail.com

${ }^{3}$ Universitas Negeri Jakarta, hilma@unj.ac.id
} 
instructional objectives. Booklet to introduce a form of coping skills in dealing with domestic violence among students of high school state 81 Jakarta can be declared "Very Feasible". Booklet consists of two parts, Part I describes the scope of domestic violence and coping skills. Part II describes the application of coping skills in dealing with domestic violence.

Keywords: ADDIE Model, booklets, coping skills, domestic violence

Peserta didik pada tingkat Sekolah Menengah Atas (SMA) rentan mengalami konflik dengan orang tua. Area konflik yang terjadi antara remaja dengan orang tua antara lain prestasi belajar, waktu bermain, pemanfaatan teknologi informasi, membantu tugas rumah, keterlambatan jam pulang, model pakaian, model rambut, perilaku pacaran dan pemilihan teman (Lestari \& Asyanti, 2009). Hal ini dikarenakan masa remaja merupakan masa dimana individu berusia 12 - 21 tahun (Santrock, 2012). Hall menyebutkan istilah "Badai dan Stres (Storm and Stress) pada masa remaja, dimana masa remaja merupakan masa bergolak yang diwarnai oleh konflik dan perubahan suasana hati (mood) (Santrock, 2012).

Pada hakikatnya masa remaja merupakan masa lanjutan dari masa kanak-kanak. Dimana terjadi perubahan-perubahan pada diri peserta didik seperti fisik, psikologis, perilaku serta kognitif sosial masa remaja. Jika pada masa kanak-kanak intensitas terhadap keluarga sangat sering, namun pada masa remaja ini individu mulai memiliki aktivitas yang sering terhadap teman sebaya dibandingkan keluarga. Pada masa remaja ini peserta didik lebih berani menuntut otonomi dan tanggung jawab yang membingungkan sehingga sering menimbulkan amarah yang menyebabkan timbulnya konflik diantara orang tua dan remaja. Pada keadaan ini orang tua akan merasa peserta didik hendak melepaskan diri dari genggaman orang tua. Orang tua akan berusaha untuk melakukan pengendalian yang lebih kuat ketika remaja menuntut otonomi dan tanggung jawab. Keadaan emosional yang memanas dapat terjadi di kedua pihak baik peserta didik maupun orang tua, dimana salah satu pihak dapat mengancam, mencaci maki dan melakukan apa saja yang perlu dilakukan untuk dapat mengendalikan keadaan (Santrock, 2002).
Standar Kompetensi Kemandirian Peserta Didik (SKKPD) menjelaskan bahwa peserta didik yang berada pada tingkat SMA pada aspek perkembangan kematangan emosional perlu untuk mempelajari cara-cara menghindari konflik dengan orang lain (Sugiyatno, n.d). Oleh karena itu dengan mendapatkan pengetahuan mengenai coping skills dapat membantu peserta didik mempelajari cara-cara menghindari konflik KDRT yang mungkin dialami.

Kekerasan dalam rumah tangga (KDRT) adalah setiap perbuatan terhadap sesama individu terutama perempuan, yang berakibat timbulnya, kesengsaraan atau penderitaan secara fisik, seksual, psikologis, dan/atau penelantaran rumah tangga termasuk ancaman untuk melakukan perbuatan, pemaksaan, atau perampasan kemerdekaan secara melawan hukum dalam lingkup rumah tangga (Hanita \& dkk., 2016). Dalam hal ini yang termasuk cakupan rumah tangga menurut Pasal 2 UUPKDRT adalah (Yunisa, n.d.): (a) Suami Isteri, dan anak (termasuk anak angkat dan anak tiri, (b) setiap individu yang mempunyai hubungan sebagaimana disebutkan di atas karena hubungan darah, perkawinan (misalnya mertua, menantu, ipar, dan besan), persusuan, pengasuhan, dan perwalian, yang menetap dalam rumah tangga; dan/atau (c) Individu yang bekerja membantu rumah tangga dan menetap dalam rumah tangga tersebut, dalam jangka waktu selama berada dalam rumah tangga yang bersangkutan. Kekerasan yang umumnya dapat terjadi pada anak adalah sebagai berikut, kekerasan fisik, kekerasan psikologis/emosional, kekerasan seksual, dan penelantaran rumah tangga (National Society for The Prevention of Cruelty to Children, 2009).

Berdasarkan hasil studi pendahuluan KDRT pada peserta didik dengan menggunakan Child Abuse Self Report Scale 
yang di lakukan di SMAN 81 Jakarta kepada kelas XII MIPA 2, XII MIPA 3 dan XII IPS2 dengan jumlah responden 108 peserta didik. Diperoleh hasil kekerasan emosional dialami oleh 12 peserta didik dengan tingkatan sedang, 18 peserta didik dengan tingkatan rendah, dan 78 peserta didik dengan tingakatan sangat rendah. Kekerasan fisik dialami oleh 1 peserta didik dengan tingkat rendah, dan 107 peserta didik dengan tingkat sangat rendah. Terakhir untuk Kekerasan seksual sebanyak 108 peserta didik berada pada tingkat sangat rendah. Berdasarkan data terlihat bahwa jumlah siswa yang mengalami KDRT tidak terlalu signifikan, namun perlu kembali diingat bahwa isu KDRT yang senstif menyebabkan kasus ini sering kali berada pada fenomena gunung es. Hal-hal yang menjadi penyebab antara lain merasa bahwa isu KDRT adalah aib keluarga, mendapatkan ancaman dari pelaku, perkataan peserta didik sulit dipercaya dibandingkan perkataan individu dewasa, masalah keluarga tidak patut di campuri oleh masyarakat, prosedur pelaporan yang belum jelas (Abdullah, 2010).

Dari hasil studi pendahuluan terhadap peserta didik yang berada pada tingkat Sedang, peneliti telah melakukan wawancara terhadap 12 peserta didik dan sebanyak 8 peserta didik mengaku sudah merasa bahwa orang tua tidak menginginkannya dan tertekan bila berada di rumah, 4 peserta didik lainnya mengaku masih memahami kesibukan dan tuntutan orang tua meskipun terkadang membuat peserta didik tertekan. Melihat dari peserta didik yang mengalami tingkat kekerasan baik rendah maupun sangat rendah, setidaknya terdapat beberapa kekerasan emosional yang umumnya hampir dirasakan oleh semua peserta didik seperti selalu mendapatkan kritikan dari orang tua dan anggota keluarga, orang tua sering menyuruh peserta didik, harapan keluarga dan orang tua tidak sesuai dengan kemampuan. Pada kekerasan fisik masalah yang banyak dialami peserta didik adalah orang tua sering memukul sehingga menimbulkan bekas, hukuman yang diberikan orang tua tidak sebanding dengan kesalahan, dan peserta didik menyaksikan KDRT di dalam keluarga. Pada kekerasan seksual beberapa peserta didik mendapatkan perkataan-perkataan seksual secara kasar dari beberapa orang dewasa di sekitarnya.
Hasil observasi yang dilakukan di salah satu lembaga yang menaungi kekerasan pada peserta didik dan perempuan yaitu Pusat Pelayanan Terpadu Pemberdayaan Perempuan dan Anak (P2TP2A) DKI Jakarta tercatat bahwa jumlah kasus kekerasan yang terjadi pada peserta didik sepanjang tahun 2017 yang di hitung sampai bulan November sebanyak 482 peserta didik. Berdasarkan gender antara peserta didik laki-laki dan perempuan yang mengalami kekerasan dari 482 peserta didik tercatat $41 \%$ peserta didik laki-laki dan $59 \%$ peserta didik perempuan. Dari berbagai macam kekerasan yang terjadi pada peserta didik, kekerasan yang paling banyak di alami peserta didik antara lain pencabulan, persetubuhan, fisik dan emosional. Rentan usia peserta didik yang mengalami kekerasan sepanjang tahun 2017 tercatat $15 \%$ usia $0-5$ tahun, $38 \%$ usia 611 tahun, dan $47 \%$ usia 12-18 tahun. Hal ini memperlihatkan rentannya peserta didik pada usia 12-18 tahun yang berada pada fase remaja mengalami tindak kekerasan oleh individuinvidu terdekat. Dari 482 kasus kekerasan peserta didik sebanyak 427 peserta didik tercatat sebagai korban, 28 sebagai saksi dan 27 sebagai pelaku kekerasan. Peserta didik yang menjadi korban dalam kasus kekerasan ini sebanyak $75 \%$ dilakukan oleh individu terdekat, $14 \%$ oleh orang tua, dan $12 \%$ oleh anggota keluarga lainnya.

Berdasarkan hasil wawancara peneliti dengan ketua lembaga P2TP2A, kasus kekerasan peserta didik yaitu pencabulan, persetubuhan dan fisik banyak terjadi pada keluarga yang berada pada ekonomi menengah kebawah, sedangkan kekerasan emosional terjadi pada keluarga dengan perekonomian menengah ke atas. Selain kekerasan terjadi dengan orang tua dan anggota keluarga lain sebagai pelaku, kekerasan pada peserta didik juga dapat dilakukan oleh individu terdekat seperti pacar yang terutama sering terjadi pada peserta didik dengan rentang usia 14-18 tahun. Kekerasan yang dilakukan ini dapat seperti persetubuhan secara paksa, fisik maupun secara emosional. Hal yang memprihatinkan lembaga P2TP2A ini adalah kebanyakan peserta didik yang melapor pada lembaga sudah dikatakan mengalami kekerasan yang cukup parah karena sebelumnya peserta didik tidak mengetahui bahwa apa yang dilakukan oleh pelaku merupakan bentuk kekerasan dan ketika sudah 
mengetahui peserta didik tidak memiliki informasi untuk melaporkan tindakan KDRT dan tidak memiliki keterampilan untuk melindungi diri.

Peserta didik perlu diperkenalkan pada keterampilan penyelesaian masalah, Lazarus dan Folkman (1984) mendefinisikan coping skills merupakan usaha untuk mengubah kognitif dan perilaku individu secara terus menerus untuk mengelola tuntutan eksternal dan/atau internal tertentu yang dinilai melelahkan atau menguras energi indiviu. Dalam hal ini peserta didik yang berada dalam situasi yang tidak nyaman melakukan suatu aktifitas yang melibatkan kemampuan kognitif dan perilaku peserta didik untuk akhirnya merubah interpretasi peserta didik terhadap situasi tersebut dan situasi tersebut berubah. Coping skillsjuga dapat dikatakan merupakan suatu proses perilaku, kognitif, dan emosional dalam mengelola stres atau situasi yang menegangkan atau mengancam pada diri peserta didik (Darity Jr, 2008).Coping skills yang dimaksud ini adalah peserta didik dapat mengkonsepkan solusi alternatif untuk keadaan stres dan melakukan relasi terhadap kemampuan emosional dan perilaku bermasalah (Compas, Marcarne, \& Fondacaro, 1988).

Berdasarkan studi pendahuluan yang telah dilakukan dengan menggunakan angket coping skills dalam situasi KDRT terhadap 12 peserta didik yang terindikasi mengalami KDRT diperoleh hasil pada kekerasan emosional 3 peserta didik memiliki tingkat coping skills yang sangat tinggi, 3 peserta didik memiliki tingkat coping skills yang tinggi, dan 6 peserta didik memiliki tingkat coping skills yang sedang. Pada kekerasan fisik 1 peserta didik yang mengalami memiliki tingkat coping skills yang tinggi. Meskipun hal ini tampak baik karena peserta didik yang terindikasi mengalami KDRT sudah memiliki keterampilan coping skills yang tinggi, namun antisipasi bagi peserta didik lain yang belum membuka diri terhadap isu KDRT perlu untuk disiapkan. Layanan BK dengan menggunakan media yang memadai tampaknya akan mendukung keberhasilan optimalisasi layanan. Peneliti juga melakukan wawancara mengenai pemahaman peserta didik mengenai cara-cara untuk mengatasi masalah atau yang dinamakan coping skills, 12 peserta didik mengaku belum pernah mendapatkan informasi mengenai cara mengatasi masalah, sehingga peserta didik tidak mengetahui bahwa yang dilakukan selama ini merupakan sebagian dari usaha untuk menyelesaikan masalah atau yang dinamakan coping skills.

Dari hasil studi pendahuluan mengenai coping skills terhadap 12 peserta didik yang terindikasi mengalami KDRT, peserta didik sudah berusaha melakukan perlindungan diri melalui coping skills tanpa disadari. Dari beberapa bentuk-bentuk coping skills yang paling banyak dilakukan oleh peserta didik adalah self control dan positive reappraisal tindakan yang dilakukan oleh peserta didik yaitu berusaha untuk tetap tenang ketika mendapatkan perlakuan yang tidak baik dari anggota keluarga serta memberikan masukanmasukan positif pada diri sehingga tetap termotivasi meskipun mendapatkan perlakuan yang kasar dari anggota keluarga.

Berdasarkan hasil studi pendahuluan di lembaga P2TP2A dan guru BK di SMAN 81 Jakarta didapatkan bahwa selama melakukan sosialisasi KDRT media yang digunakan adalah power point, video, booklet. Sementara di SMAN 81 Jakarta guru BK jarang memberikan informasi mengenai isu keluarga terutama KDRT karena berfokus pada perguruan tinggi. Adapun media yang digunakan adalah video, power point, poster dan booklet. Namun baik di lembaga P2TP2A dan SMAN 81 Jakarta booklet yang digunakan belum menjelaskan secara detail mengenai bagaimana coping skills yang dapat dilakukan oleh peserta didik ketika mengalami KDRT. P2TP2A hanya membuat booklet yang menjelaskan prosedur pelayanan P2TP2A dan SMAN 81 Jakarta mendapatkan booklet dari perguruan tinggi terkait karir dan bukan upaya prefentif atau kuratif terkait KDRT.

Lembaga P2TP2A mengatakan booklet lebih mudah digunakan untuk membuat responden terus mengingat informasi yang diberikan karena dapat dibaca ulang dan lebih singkat serta terdapat gambar untuk mendukung agar lebih mudah dipahami. Guru BK juga mengatakan lebih mudah menjelaskan informasi menggunakan booklet karena peserta didik dapat membaca sendiri dan bisa berulang kali membaca. Hasil wawancara terhadap 12 
peserta didik yang mengisi angket coping skills terdapat 8 peserta didik setuju untuk guru BK menggunakan booklet dalam memberikan informasi karena dapat dibaca berulang kali.

- Memperhatikan efektifitas booklet dan kelebihan-kelebihan yang dimilikinya, maka peneliti merasa perlu mengembangkan media booklet untuk memperkenalkan bentuk-bentuk coping skills dalam menghadapi kekerasan dalam rumah tangga untuk peserta didik. Booklet merupakan buku berukuran kecil (setengah kuarto) yang terdiri dari satu atau tidak lebih dari 48 halaman yang dijilid diagian engah sekaligus dengan sampulnya (Satmoko \& Astuti, 2006).

\section{METODE PENELITIAN}

Penelitian ini menggunakan metode Research and Development (RnD) dengan model ADDIE (Analysis, Design, Development, Implementation, and Evaluation). Konsep ADDIE diterapkan untuk membuat sebuah produk pembelajaran berbasis performa, filosofi pendidikan untuk penerapan ADDIE ini adalah pembelajaran yang sengaja berpusat pada peserta didik, inovatif, otentik dan inspirasional. Dalam mengembangkan sebuah produk dengan menggunakan model ADDIE merupakan sebuah kegiatan dengan menggunakan perangkat yang efektif (Branch, 2009).

Tahapan ADDIE pada penelitian ini terdiri dari; (1) Analisis, merupakan tahapan yang meliputi pelaksanaan analisis kebutuhan dan identifikasi masalah (Hadi \& Agustina, 2016);

(2) Desain, merupakan tahapan untuk melakukan penetapan kinerja yang akan dicapai dan melakukan pemilihan metode tes yang sesuai untuk pengembangan produk (Branch, 2009); (3) Pengembangan, merupakan tahapan untuk produk yang telah direncanakan dibuat menjadi nyata atau real terlihat dan dapat digunakan. Tahapan ini dapat disebut sebagai kegiatan merealisasikan perencanaan poduk yang telah dibuat (Branch, 2009). Penelitian ini tidak sampai pada tahap implementasi dan evaluasi dikarenakan keterbatasan akan waktu dan juga biaya yang digunakan dalam penelitian ini.

Populasi pada penelitian ini adalaha peserta didik di SMA Negeri 81 Jakarta kelas XII. Teknik sampling yang digunakan dalam penelitian ini adalah judgemental sampling.
Teknik pemilihan sample ini dilakukan berdasarkan penilaian atau pandangan peneliti berdasarkan kasus atau tujuan penelitian (Amirullah, 2015).

Dalam mengumpulkan data peneliti menggunakan Instrumen dan wawancara. Dalam melakukan uji coba ahli materi dan media serta uji pilot test pada kelompok kecil peneliti menggunakan instrumen penilaian. Pada saat uji pilot test peneliti melakukan sesuai dengan tahapan pada RPL namun hanya sampai pertemuan pertama saja.

\section{HASIL PENELITIAN}

Tuliskan deskripsi hasil penelitian serta keterbatasan penelitian)

Berdasarkan perencanaan yang telah disusun maka penelitian ini dapat dijelaskan seperti,

Pertama, pada tahap analisis peneliti melakukan studi pendahuluan untuk mengukur kesenjangan antara keadaan yang sebenarnya dengan keadaan yang seharusnya. Dari hasil studi pendahuluan peneliti menentukan tujuan instruksional serta karakteristik pengguna media. Selanjutnya peneliti membuat perencanaan seperti menentukan informan, menyusun konten, membuat desai, uji ahli dan melakukan pencetakkan.

Kedua, pada tahapan desain peneliti perlu mencocokkan konten yang akan dibuat dengan tujuan yang ingin dicapai dalam pengembangan media booklet ini. Selanjutnya peneliti perlu membuat item tes yang akan digunakan setelah pengguna membaca booklet. Selanjutnya peneliti juga perlu memperkirakan biaya yang akan dikeluarkan selama pengembangan booklet.

Ketiga, pada tahapan pengembangan dikarenakan booklet memiliki keterbatasan halaman dan materi yang disampaikan cukup banyak maka peneliti membagi booklet menjadi dua bagian. Bagian pertama membahas mengenai ruang lingkup KDRT dan coping skills. Bagian kedua menjelaskan penerapan coping skills dalam menghadapi KDRT. Untuk memudahkan pembaca dalam menggunakan booklet maka peneliti membuat petunjuk penggunaan produk sebagai alat instruksional kepada pembaca. Selanjutnya peneliti melakukan evaluasi formatif dengan uji ahli media, ahli materi dan uji pilot test pada 
kelompok kecil yaitu 11 peserta didik SMAN 81 Jakarta.

\begin{tabular}{llcc}
\hline No & Aspek & $\begin{array}{c}\text { Rata-Rata } \\
\text { Persentase }\end{array}$ & Kategori \\
\hline 1 & Desain & & \\
2 & Bahasa & & Sangat Layak \\
3 & Ilustrasi & $98 \%$ & \\
4 & Tipografi & & \\
5 & Lay Out & \\
\hline \multicolumn{4}{c}{ Tabel 1. Hasil Uji Ahli Media }
\end{tabular}

\begin{tabular}{llcc}
\hline No. & \multicolumn{1}{c}{ Aspek } & $\begin{array}{c}\text { Rata-rata } \\
\text { Persentase }\end{array}$ & Kategori \\
\hline 1 & Materi & & \\
2 & Kekerasan & & \\
& Dalam Rumah & & Sangat \\
& Tangga & $90 \%$ & Layak \\
& (KDRT) & & \\
3 & Coping skills & & \\
4 & Bahasa & & \\
5 & Ilustrasi & & \\
\hline & Tabel 2. Hasil Uji Ahli Materi Pertama
\end{tabular}

\begin{tabular}{clcc}
\hline No. & \multicolumn{1}{c}{ Aspek } & $\begin{array}{c}\text { Rata-Rata } \\
\text { Persentase }\end{array}$ & Kategori \\
\hline 1 & Materi & & \\
2 & Kekerasan & & \\
& Dalam & & Sangat \\
& Rumah & $95 \%$ & Layak \\
& Tangga & & \\
& (KDRT) & & \\
3 & Coping skills & & \\
4 & Bahasa & & \\
5 & Ilustrasi & & \\
\end{tabular}

Tabel 3. Hasil Uji Ahli Materi Kedua

\begin{tabular}{clcc}
\hline No. & Aspek & $\begin{array}{c}\text { Rata-Rata } \\
\text { Persentase }\end{array}$ & Kategori \\
\hline 1 & Desain & & \\
2 & Materi & $93 \%$ & Sangat Layak \\
3 & Bahasa & & \\
4 & Ilustrasi & \\
\hline \multicolumn{4}{l}{ Tabel 4. Hasil Uji Pilot Test (Penilaian Media) }
\end{tabular}

Berdasarkan hasil uji ahli yaitu ahli media dan ahli materi. Ahli media mendapatkan persentase sebesar $98 \%$ (Tabel 1) yang termasuk kategori sangat layak, ahli materi pertama mendapatkan persentase sebesar $90 \%$ termasuk kategori sangat layak dan ahli materi kedua mendapatkan persentase sebesar $95 \%$ yang termasuk dalam kategori sangat layak. Uji Pilot Test pada 11 peserta didik SMAN 81 Jakarta dengan dua penilaian. Pada penilaian media mendapatkan persentase sebesar 93\% yang termasuk dalam kategori sangat layak. Penilaian ketercapaian tujuan instruksional mendapatkan persentase sebesar $83 \%$ yang termasuk dalam kategori sangat layak.

Penelitian ini memiliki beberapa keterbatasan, pertama pada bagian konten peneliti tidak banyak mengubah pembahasan sehingga masih terdapat beberapa penjelasan yang masih berada pada sudut pandang seorang istri, seharusnya sudut pandang penjelasan booklet berfokus pada anak saja. Kedua adalah peneliti tidak banyak membahas mengenai seorang anak laki-laki yang mengalami kekerasan seksual seperti kasus sodomi yang dialami oleh anak laki-laki yang dilakukan oleh ayah atau saudara laki-laki.

Ketiga yaitu pada pelaksanaan uji coba pilot atau pilot tes peneliti tidak melakukan semua tahapan pada RPL yang telah dipersiapkan. Hal ini dikarenakan keterbatasan peneliti dalam mencetak booklet sehingga hanya mampu melaksanakan pilot tes dengan 11 peserta didik serta keterbatasan waktu pelaksanaan dikarenakan RPL dibuat untuk dua kali pertemuan bimbingan klasikal.

Keempat pada booklet bagian II tepatnya penjelasan problem solving skills kekerasan seksual peneliti tidak menjelaskan secara detail, seperti tidak membahas semua bentuk-bentuk coping skills untuk jenis-jenis kekerasan seksual. Terutama pada bentuk kekerasan seksual yang ringan hingga yang terberat. Selain kekerasan seksual seharusnya juga dijumpai penjelasan mengenai kekerasan fisik, kekerasan psikologis dan penelantaran rumah tangga yang juga dialami peserta didik. Kelima masih pada booklet bagian II pada penjelasan problem solving skills untuk penelantaran rumah tangga mengenai pemberian nafkah, peneliti tidak menjelaskan secara detail mengenai nafkah lahir dan batin yang tidak diberikan oleh seorang ayah dan terlalu spesifik membahas mengenai aturan salah satu agama yaitu agama islam.

Terakhir pada saat melakukan studi pendahuluan untuk analisis kesenjangan peneliti tidak melakukan preliminary study pengetahuan peserta didik mengenai KDRT. 
Peneliti hanya melakukan preliminary study mengenai pengetahuan peserta didik mengenai coping skills. Peneliti hanya melakukan preliminary study mengenai coping skills kepada 12 peserta didik yang terindikasi mengalami KDRT. Sehingga preliminary study tidak dilakukan kepada semua peserta didik di SMAN 81 Jakarta.

\section{KESIMPULAN}

Berdasarkan penilaian yang didapatkan pada uji ahli media, uji ahli materi dan pilot test pada 11 peserta didik dapat disimpulkan bahwa booklet berada pada kategori sangat layak. Hal ini didukung dengan desain yang menarik, ilustrasi yang menarik dan pemilihan warna yang sesuai dengan karakteristik peserta didik di SMAN 81 Jakarta, informasi yang dimuat sangat penting untuk disampaikan kepada peserta didik serta penjelasan yang mudah dipahami. Selain keunggulan yang didapatkan terdapat beberapa saran dan masukan yang diberikan oleh ahli media dan ahli konten. Masukan yang diberikan oleh ahli media yaitu perubahan pada jenis font yang sebelumnya Times New Roman menjadi jenis font Young. Masukan dari ahli konten 1 yaitu penjelasan booklet sebaiknya berfokus pada anak sehingga penjelasan yang diposisikan untuk istri sebaiknya diperbaiki, pada penjelasan lembagalembaga yang menangani kasus KDRT sebaiknya ditambahkan penjelasan petunjuk halaman yang berisi daftar lembaga-lembaga yang menangani kasus KDRT, serta pada penjelasan kasus pemerkosaan sebaiknya tidak hanya menjelaskan kasus pemerkosaan terhadap anak perempuan tetapi juga anak lakilaki. Terakhir masukan dari ahli konten 2 yaitu memperbaiki tata letak antara judul dengan subjudul karena menyebabkan kekeliruan ketika membaca, memperbaiki kata-kata yang dirasa tidak formal dan kurang pantas, menambahkan keterangan mengenai lembaga-lembaga perlindungan dan rumah sakit rujukan, serta penjelasan pada kasus pemerkosaan peneliti terlalu mensubjektifkan kepada ayah sehingga diperbaiki menjadi anggota keluarga.

Penelitian ini juga memiliki beberapa kekurangan selain tidak sampai melakukan tahapan implementasi dan evaluasi. Kekurangan lain dalam penelitian ini yaitu masih terdapat beberapa penjelasan yang berada pada sudut pandang seorang istri, peneliti tidak banyak menjelaskan kasus pemerkosaan yang dialami oleh anak laki-laki, dan pada uji coba pilot tes peneliti tidak melakukan semua tahapan pada RPL dikarenakan keterbatasan dalam pencetakkan booklet serta waktu pelaksanaan yang dilakukan.

Demi menyempurnakan penelitian ini peneliti menyarankan kepada mahasiswa BK atau guru BK dapat melanjutkan penelitian ini sampai pada tahap evaluasi sehingga kefektivitasan media dapat diketahui. Penggunaan booklet ini dapat guru BK jelaskan dengan mebahas beberapa isu KDRT yang perlu pesera didik ketahui seperti kasus pemerkosaan, penjualan anak, dan pemaksaan kerja terhadap anak. Guru BK dapat mengimplementasikan booklet dengan menggunakan RPL yang telah disediakan sehingga tahapan RPL terlaksana dan dapat melihat hasil dari penggunaan booklet yang telah dikembangkan melalui evaluasi yang telah disiapkan.

Dikarenakan minat peserta didik cukup tinggi pada booklet ini sehingga booklet ini dirasa perlu untuk digunakan pada peserta didik melalui bimbingan klasikal yang disampaikan oleh guru BK. Booklet ini dapat menjadi sarana preventif untuk mencegah peserta didik tidak memiliki kemampuan ketika menghadapi kasus KDRT, hal ini dapat tercapai dengan bantuan guru BK dalam membarikan informasi materi dalam booklet ini

\section{DAFTAR PUSTAKA}

Abdullah, N. (2010). Kekerasan Terhadap Anak "Bom Waktu" Masa Depan. Magistra, 22(73), 65-73.

Amirullah. (2015). Metode Penelitian Manajemen. Malang: Bayumedia Publishing.

Branch, R. M. (2009). Instructional Design-The ADDIE Approach. New York: Springer.

Compas, B., Marcarne, V., \& Fondacaro, K. (1988). Coping With Sressful in Older Children and Young Adolescents. Journal of Consulting and Clinical Psychology, 54(3), 405-411.

Darity Jr, W. A. (2008). International Encyclopedia of the Social Sciences (Vol. 2nd). Detroit: Macmillan Reference USA. 
Edwards, J. R., Caplan, R. D., \& Harrison, R. V. (1998). Person-environment fit theory: conceptual foundations, empirical evidence, and direction for future research. In C. L. Cooper, Theories of organizational stress (pp. 28-67). Oxford: Oxford University Press.

Evans, K. M., \& Larrabee, M. J. (2002). Teaching the multicultural counseling competencies and revised career counseling competencies simultaneously. Journal of Multicultural Counseling and Development, 21-39.

Gall, D. M., Gall, P. J., \& Borg, R. W. (2003). Educational Research: An Introduction. Boston: Ablongman.

Gustafon, K. L., \& Branch, R. M. (2002). Survey of instructional Development models. New York: ERIC Clearinghouse on Information and Technology.

Hadi, H., \& Agustina, S. (2016, Juni). PEngembangan Buku Ajar Geografi DesaKota Menggunakan Model ADDIE. Jurnal Educatio, XI(1), 90-105.

Hanita, M., \& dkk. (2016). Buku Panduan HakHak Korban Kekerasan dalam Rumah Tangga. Jakarta: Pusat Pelayanan TerpaduPemberdayaan Perempuan dan Anak (P2TP2A).

Lazarus, R. S., \& Folkman, S. (1984). Stress, Appraisal, and Coping. New York: Springer Publishing Company.

Lestari, S., \& Asyanti, S. (2009, Agustus). Area Konflik Remaja Awal Dengan Orang Tua: Studi Kuantitatif Pada Keluarga di Surakarta. Jurnal Penelitian Humaniora, 10(2), 130-137.

Lofquist, L. H., \& Dawis, V. R. (1991). Essentials of person-environmentcorrespondence counseling. Minneapolis: University of Minnesota Press.

Marini, I., \& Stebnicki, M. A. (2009). The professional counselor's desk reference. New York: Springer.
Michael Page. (2015). 2015 Employee Intentions Report Indonesia. Jakarta: Michael Page.

National Society for The Prevention of Cruelty to Children, N. (2009, April). Child Protection Fact Sheet The Definitions and Signs of Child Abuse. NSPCC Inform The Online Child Protection Resource, 1-7.

Osborn, D. S., \& Baggerly, J. N. (2004). School counselors' perceptions of career counseling and career testing: preferences, priorities, and predictors. Journal of Career Development, 31(1), 45-59.

Randang, F. B. (2011). Kesiapan Tenaga Kerja Indonesia dalam Menghadapi Persaigan dengan Tenaga Kerja Asing. Servanda, 66-73.

Rogers, M., \& Creed, P. (2000). School-towork transition: from theory to practice. Journal of Career Development, 9(3), 121.

Santrock, J. W. (2002). Life-Span Development, Perkembangan MasaHidup (5 ed.). Jakarta: Erlangga.

Santrock, J. W. (2012). Life-Span Development, Perkembangan MasaHidup (13 ed.). Jakarta: Erlangga.

Satmoko, S., \& Astuti, H. T. (2006). Pengaruh Bahasa Booklet pada Peningkatan Pengetahuan Peternak Sapi Perah Tentang Inseminasi Buatan di Kelurahan Nongkosawit, Kecamatan Gunungpati, Kota Semarang. Jurnal Penyuluhan, 2(2), 78-82.

Sugiyatno. (n.d). Standar Kompetensi Kemandirian (SKK). Yogyakarta: Universitas Negeri Yogyakarta.

Yunisa, N. (n.d.). Undang-Undang R.I. No. 23 Tahun 2004 tentang Penghapusan Kekerasan Dalam Rumah Tangga (KDRT). Jakarta: Permata Press. 


\section{Lampiran}

\section{booklet}

COPING SKILLS UNTUK MENGHADAPI KEKERASAN DALAM RUMAH TANGGA (KDRT) PADA ANAK

BAGIAN 1
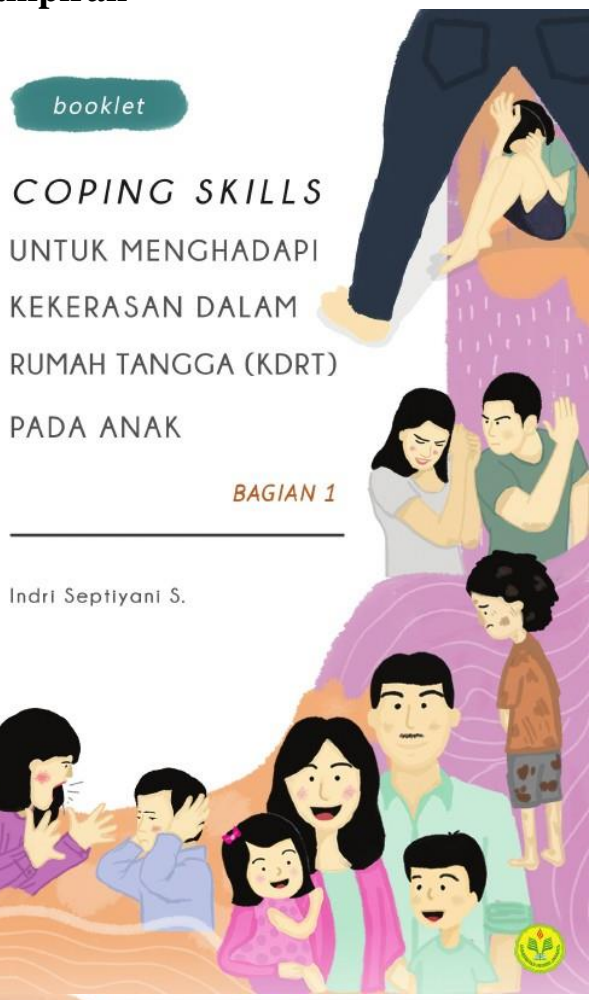

PENGERTIAN COPING SKILLS

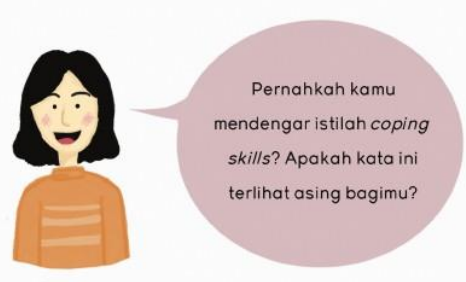

Mungkin bagi sebagian dari kalian baru mendengar kata coping skills setelah membaca booklet ini.

Namun, perlu diketahui bahwa coping skills sering kita lakukan disaat kita mengalami masalah atau berada pada situasi tertekan.

Setelah membahas mengenai KDRT, sekarang kita akan membahas sedikit mengenai coping skills.

Penjelasan lebih mendalam akan kita bahas di booklet bagian II.

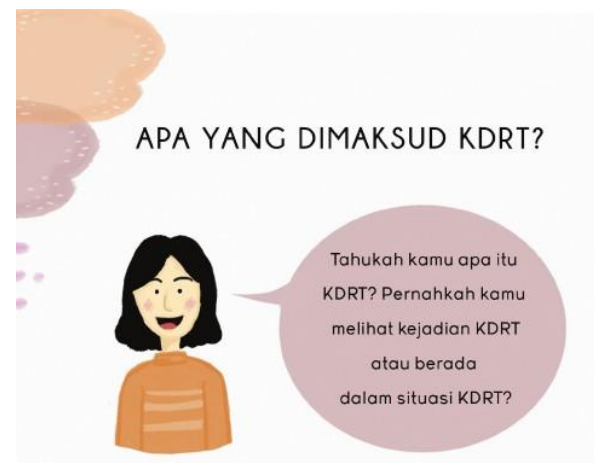

Kekerasan dalam rumah tangga atau yang disingkat KDRT merupakan suatu perbuatan yang menyakiti seseorang terutama perempuan, sehingga menimbulkan penderitaan secara fisik, seksual, psikologis atau emosional, dan penelantaran rumah tangga dengan melakukan ancaman, pemaksaan, atau perampasan kemerdekaan (Hanita \& dkk, 2016).

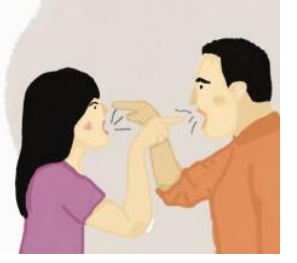

MACAM-MACAM KDRT

Banyak orang yang hanya mengetahui dan memfokuskan diri pada kekerasan fisik yang memang lebih nampak terlihat.

Namun perlu diketahui terdapat 4 macam bentuk KDRT yang dapat merugikan anggota keluarga yang menjadi korban, antara lain:

\section{KEKERASAN FISIK}

Kekerasan fisik merupakan suatu bentuk kekerasan yang dilakukan oleh pelaku yang mengacu pada luka yang disengaja untuk melukai korban sehingga menimbulkan rasa sakit, jatuh sakit, atau luka berat yang dialami korban (Carr, 2006).

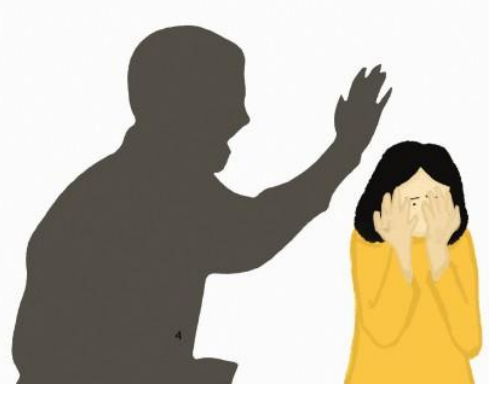



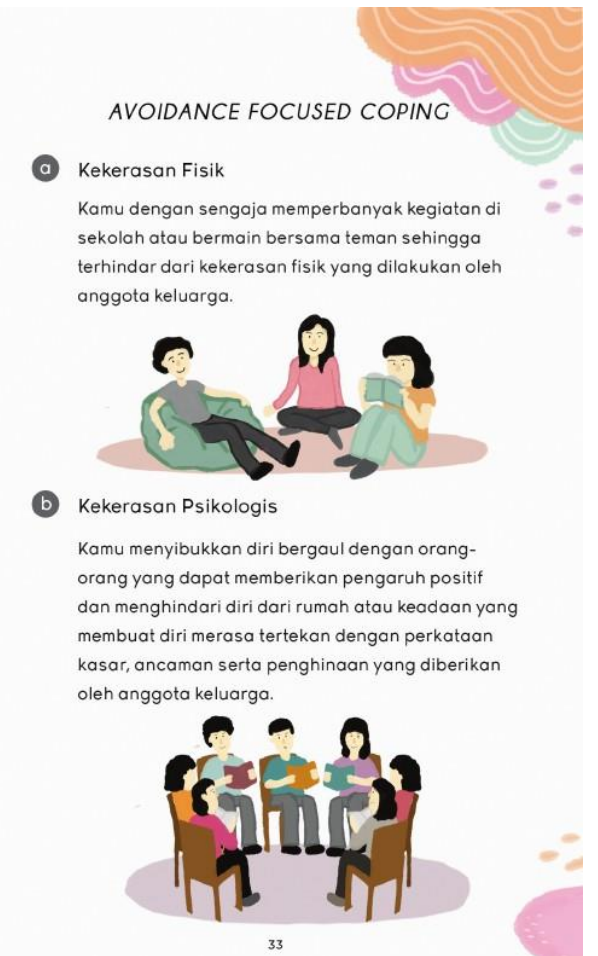

\section{booklet}

\section{COPING SKILLS}

UNTUK MENGHADAPI

KEKERASAN DALAM

RUMAH TANGGA (KDRT)

PADA ANAK

BAGIAN 2
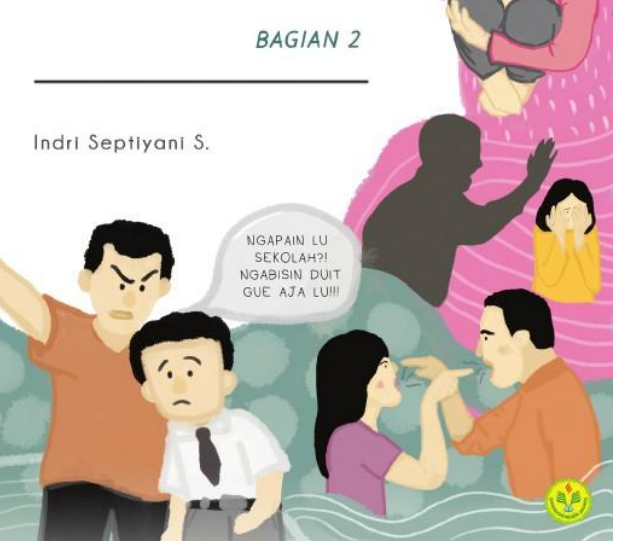

EMOTIONAL FOCUSED COPINC

Self Control

(c) Kekerasan Fisik

Ketika kamu mendapatkan perlakuan kekerasan

fisik berusaha untuk menahan diri dan emosi

kamu agar tidak membuat pelaku semakin

bernafsu menyakiti kamu secara fisik. Hal yang

harus kamu lakukan adalah:

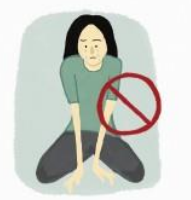

1. Usahakan diri untuk 2. Tidak memberontak tidak menangis. dengan amarah yang tinggi:
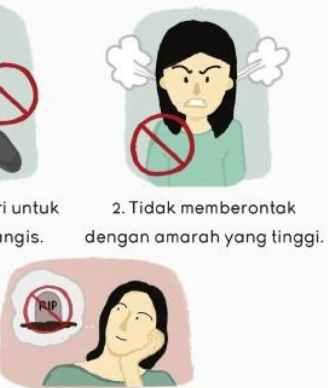

3. Tidak melakukan hal yang diluar kendali sehingga merugikan diri sendiri, seperti bunuh diri dan menyakiti pelaku.

PROBLEM FOCUSED COPING

Confrontative Coping

a Kekerasan Fisik

Ketika kamu menjadi korban KDRT, kamu memiliki hak untuk dapat melakukan perlawanan ketika pelaku mencoba untuk melukai dirimu. Yaitu dengan cara:

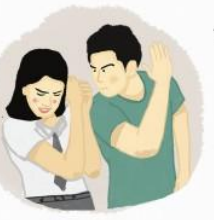

Menghindar ketika pelaku hendak menyakitimu dengan cara menahan pelaku dan segera pergi menjauh dari pelaku.

. Berani berbicara kepada pelaku untuk menghentikan perbuatan tersebut.

Contoh:

"Stop ayah! Aku ini anak ayah, tidak sepantasnya ayah menyakitiku."

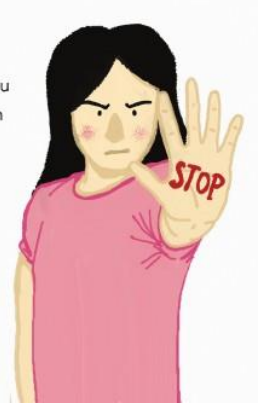

